\title{
Critical Sámi Research as the Means of Finding Ways of Seeing
}

\author{
Erika Sarivaara \\ University of Lapland \\ Ventäjäntie 6, 99870 Inari, Finland
}

Tel: 358-45-124-1656 E-mail: erika.sarivaara@gmail.com

\author{
Satu Uusiautti (Corresponding author) \\ University of Lapland
}

PO Box 122, 96101 Rovaniemi, Finland

Tel: 358-40-484-4167_E-mail: satu_uusiautti@hotmail.com

\author{
Kaarina Määttä \\ University of Lapland \\ PO Box 122, 96101 Rovaniemi, Finland \\ Tel: 358-400-696-480Ｅ-mail: Kaarina.Maatta@ulapland.fi
}

Received: August 1, 2013 Accepted: September 8, 2013 Published: November 7, 2013

doi:10.5296/ijssr.v2i1.4521ＵRL: http://dx.doi.org/10.5296/ijssr.v2i1.4521

\begin{abstract}
The Sámi form a small indigenous people living in four countries, Norway, Sweden, Finland, and Russia. The situation of the Sámi populations in these countries is challenging mostly because of colonial history, and new ways of researching and developing their conditions are greatly needed. The purpose of this article is to contemplate the potentials that the critical theory and research could offer to Sámi research and to indigenous research in general. The problems of cultural identity in relation to the mainstream society and within the indigenous community are discussed as the target of critical research and reflection. The value of critical
\end{abstract}


research as the enhancement of emancipation and empowerment are evaluated.

Keywords: Sámi, indigenous, critical research, critical theory, Sámi research, indigenous research, empowerment, emancipation

\section{Introduction}

In this article, we will discuss what critical Sámi research is and why a critical approach is needed. First, we introduce some of the historical trends and significant turning points of Sámi research, and then view them in the light of critical indigenous research. The aim in this article is to approach the critical Sámi research from a theoretical perspective by immersing in the literature and theories of both critical indigenous and Sámi research in general. The purpose is also to show how the critical approach can benefit indigenous research, not only when it comes to the rights of indigenous people in relation to the mainstreaming populations and governments but also within the indigenous communities. Basically, critical Sámi research can be called a branch of research covering various approaches and theoretical perspectives that share critical interest in information and multidimensional emancipation (e.g., Heyd, 1995). Research pursues a change for just and culturally strong society and for self-determination (Kincheloe \& McLaren, 2005). Furthermore, the aspiration is to pull down colonialist structures, assimilation, and stereotypes (Kuokkanen, 2009).

Central themes in indigenous and Sámi research have lately covered various analyses and constructs for example of identity, ethnicity, indigenous epistemology and knowledge structures, hegemony, colonization, and globalized world. These viewpoints are based on the history of indigenous peoples which is affected by colonization. The power relations related to this development give birth to otherness (Kuokkanen, 2009; Seurujärvi-Kari, 2012).

The post-colonialist theory is a central approach in Sámi research. The principles of the theory can be described for example as criticism of a Eurocentric view (Kymlicka, 1998; see also Williams \& Finger Wright, 1992). In addition, it tries to bring out ways of representation and mechanisms that lie behind them and offer options to established ways of representation. Thus, post-colonialist theory is politically motivated and ideologically aiming at dismantling distortions (Kuortti, 2007).

Veli-Pekka Lehtola (2005) distinguishes two emphases in Sámi research. The first focuses on the development and critical analysis of Sámi self-determination and Sámi society. The criticism toward the power structures of the mainstreaming society has expanded to the critical analysis of the Sámi's own political and societal power structures. Lehtola continues that the second emphasis covers the position of the Sámi within the Nordic society. Then, the target of analysis is the relationship between countries and the Sámi population, and the relationships between local populations. Sámi research is multidisciplinary in nature as the research covers the fields of law, linguistics, education, history, and tourism research.

According to our understanding, critical Sámi research can be roughly divided into two trends with different targets of analysis. The first dissects critically the relationship between the Sámi community and authorities based on the post-colonialist theory (Hirvonen, 1999; Keskitalo, Määttä, \& Uusiautti, 2013; Kuokkanen, 2009; Porsanger, 2007; Seurujärvi-Kari, 
2012) whereas the second trend focuses critical interest in the inner structures and power relations of the Sámi community (Eikjokk, 2000; 2007; Gaski, 2000; 2008; Hovland, 1996; Stordahl, 1996; Valkonen, 2009). However, one has to pay attention that this division in the field of critical Sámi research is highly simplistic; several research include both emphasis and crossed aspects.

Sámi research means research that is conducted from the Sámi point of view. Primarily, the purpose of Sámi research is to produce emancipatory information and to change and renew research through critical discussion (Länsman, 2008). Emancipatory information relates to critical social sciences and power. It tries to reveal regularities of societal action and ideological interdependences of it (Habermas, 1976). Sámi research is expected to benefit the Sámi community. In addition, a Sámi researcher (when understood as a person doing Sámi research) defines in his or her study which groups and areas belong to the Sámi community (see also Länsman, 2008).

\section{Lappology Preceded Sámi Research}

Sámi research was preceded by a Lappologist research tradition. Lappology described Sámi culture from an outsider's point of view all the way from the 17th century to the end of the 20th century. The tradition started when Johannes Schefferus published a book called "Lapponia" in 1673. The book was based on manifold research on the Sámi (Lehtola, 1996; Seurujärvi-Kari, 2012). However, Schefferus himself did not visit Lapland but his studies were based on contemporary descriptions (Vahtola, 1983). This work also has a significant role as it contains plenty of Sámi poetry. Schefferus received two epic Sámi texts from a Kemi-Sámi priest and poet Čearbmá Ovllál aka Gumppe Ovllál aka Olaus Sirma (b. 1650- d. 1719). The first one is originally named as Kulnasatz and the other one Pastos päivva kiufvresistjavra Orrejavra (Pulkkinen, 2000; Schefferus, 1963; Seurujärvi-Kari, 2012).

The scientific research of Lappology was conducted in a period when colonialism, imperialism, nationalism, social Darwinism, and cultural racism prevailed (Schanche, 2002). Sámi research tries to distinguish from the old tradition of Lappology that has been described as biased by prejudices, evolutionist-romantic, and exotic search of a human being (Kulonen et al., 2005). On the other hand, according to Lehtola (2005), rigorous Lappology research could be nationally and internationally beneficial as he considers the tradition as an important part of basic research, research on mainstreaming populations, and European cultural history.

In Sámi research, information is produced from the Sámi perspective and the purpose is to empower the Sámi community by showing and dismantling colonizing structures and practices. The Sámi perspective means that the voices arising from the Sámi culture and community are being brought out by the means of Sámi research. Based on these premises, the paradigm of Sámi research has been developed by for example Balto $(1997 ; 2008)$, Hirvonen (1999; 2003), Keskitalo (2010), Kuokkanen (2007), Lehtola (1997), Porsanger (2007), Seurujärvi-Kari (2012), and Valkonen (2009). One important task of Sámi research is to produce research in the Sámi language. The Sámi language has to be developed as a language of science. The use of Sámi language in the scientific arena promotes the situation of the language and especially its terminology. In addition, it has a positive influence on the 
status of the language (Breie Henriksen, 2004; Eriksen, 2007; Keskitalo, 2010; Rautio Helander, 2008).

Sámi research is a part of global discourse of indigenous research (Hart, 2010). The discourse of indigenous research emphasizes the ethicality of and researcher positions in research (Smith, 1999). Indeed, indigenous peoples have moved toward the new research paradigm since the 1990s. The purpose of post-colonialist research and decolonization processes is to help indigenous peoples to survive with the influence of colonialist history, hegemony, and other suffering (Kuokkanen, 1999). The goal of indigenous research paradigms is to construct new kinds of viewpoints to research by questioning and deconstructing the prevailing values, viewpoints, and knowledge systems. These research paradigms can offer new means of analyzing indigenous cultures which partly decreases the chances of misinterpretations. The development of indigenous research paradigm is part of the process of gaining self-determination (Kuokkanen, 2002).

\section{Critical Theory and Methodology}

The critical research tradition aims at liberating and empowering people from inequitable social circumstances (e.g., Chambers, 2006; Stromquist, 2013). Thus, critical theory analyzes such societal conditions that prevent people from realizing their potential (e.g., Pietilä, 2009), and that could enhance the development of awareness (e.g., FitzSimmons \& Uusiautti, 2013). Critical theory was powerfully developed by the Frankfurt school of sociology born in the 1920s and based on mostly Marxist thinking and multidisciplinary approaches.

The most remarkable original theorists of this tradition were Theodor Adorno (b. 1903 - d. 1969) and Max Horkheimer (b. 1895 - d. 1973), the current ones being for example Jürgen Habermas and Axel Honneth (Kiilakoski \& Oravakangas, 2010; Suoranta, 2005). What is worth noticing is that although critical researchers have posed controversial views and they have different theoretical insights, they share the endeavor of surpassing the separation of theory and empirical research and avoiding the fragmented nature typical of specialized sciences (Held, 1987; Huttunen, 2003).

Criticism of colonization and post-colonist theory relate to critical theory too as they take a critical stand against the western values and ethnocentric viewpoint. Franz Fanon (1959; 1961 ; 1967) opened discussion about the influence of colonialism on human thinking, in other words, its psychological and sociological effects. The colonization process involves the ruling powers' attempt to change the indigenous languages and cultures due to which the dominant language has widely replaced the Sámi language, and for example, Christianity was used as a means of getting rid of the Sámi culture and spiritual traditions and rites (see Kuokkanen, 2006; Lehtola, 1997). The Sámi people's encounter with the authorities has been described in research literature as colonialist because what followed was the subordination of the Sámi culture, dispersing the traditional Sámi residential area and their social and cultural structures (Hirvonen, 1999; Kuokkanen, 1999; Minde, 2005; Niemi, 1997).

Habermas $(1976 ; 1987)$ divided scientific research types into three groups based on their interests in information. The first one is the technological knowledge which is known from 
positivist research attempting at controlling the nature. The second is practical or hermeneutic interest pursuing better understanding of human action. The third is emancipatory or liberating interest related to interaction between people and social institutions. The latter looks for societal regularities and reveals the unconscious power relationships included in them. On the other hand, for example, Connelly (1996) has criticized Habermas's critical ideas too theoretical and hard to apply at the practical level. Still, Habermas showed that the emancipation can be the way of criticizing and challenging the western ideology and dominance (see also Ecclestone, 1996).

Given the obvious need for practical solutions, we would also like to refer to the ideas of Paulo Freire, who presented the idea between practice and reflection through the concept of "praxis". Action without reflection is, according to Freire, activism, whereas reflection without action just verbalism (Freire, 1972). Freire also introduced the concept of conscientization that is very applicable when viewing the emancipation of indigenous peoples. Critical thinking, or conscientization, means "a critical comprehension of man as a being who exists in and with the world" (Freire, 1970, p. 452). According to our understanding that the way critical research can be applied to enhance the liberation is the ability to fight against individual and collective oppression which in turn necessitates consciousness not only toward the ruling powers but also toward the own community.

Indeed, critical research can change practices (Kiilakoski \& Oravakangas, 2010). The critical research approach promotes the subjectivity of knowledge and equality. This means that such settings are employed in which the epistemologically and existentially equal learn from each other. Typical research methods are participatory ethnography and action research, and other participatory methods (e.g., Collins, 2009; Díaz de Rada, 2007; Ecclestone, 1996) and approaches that involve the researcher inside and within the social reality of the research target (e.g., Rosaldo, 1980). Thus, the research, promoting and improving the conditions, becomes a shared task (e.g. Botes \& van Rensburg, 2000). Methodological choices and questioning are based on the researcher's understanding of the reality and his or her opportunity of obtaining information about it (Sarivaara, Määttä, \& Uusiautti, 2013). These ontological and epistemological presumptions direct the research process.

Multidisciplinary and critical Sámi research cannot be evaluated by criteria of just one discipline because the premises, principles, and methods can vary considerably. The question of how knowledge is understood is culminated in the debate regarding research methods used (Lehtola, 2005). The positivist philosophy of science emphasizes the unity of science according to which all science is part of the same entity and all scientific explanations must follow the same laws (see also Hendrickson \& McKelvey, 2002). Thus, it is necessary to pose argument that can be proved either right of wrong by scientific research (Anttila, 2006). On the other hand, the constructivist approach criticizes positivism because it thinks that an objective reality does not exist. Knowledge is subjective and constructed by individuals' unique experiences (see also Marker, 2000). Whereas hermeneutical understanding of reality defines knowledge as historical, time-, and place-bound. The researcher's role is active and he or she is considered a part of the research process. In addition, the interpretation does not directly describe the target but is transmitted through multiple interpretations. 
Critical research can apply a variety of methods. For example, critical action research is based on the philosophical tradition of critical theory in which action research is regarded as a means of changing and influencing the society. One of the most influential books in this branch has been Wilfred Carr and Stephen Kemmis's (1986) Becoming Critical. The critical viewpoint of action research is based on Kurt Lewin's idea of being able to answer social questions through actions research. The social viewpoint was further crystallized by the critical theory introduced by the Frankfurt school. The purpose of critical action research is to pursue justice, emancipation, and individuals' self-determination. This kind of research aims at liberation, empowering, and participation (Heikkinen, 2001; see also Carr \& Kemmis, 1986).

Research methodology has been significantly implicated in the playing out of historical tensions related to power and control of research process between indigenous peoples and the wider research community (Henry et al., 2004). Linda Tuhiwai Smith (1999) has contributed to the elevation of research methodology. She argues that when conducting indigenous research the researcher critically reflect on the following questions: (1) What research do we want done?; (2) Whom is it for?; (3) What difference it will make?; (4) Who will carry it out?; (5) How do we want the research done?; (6) How will we know is it worthwhile?; (7) Who will own the research?; and (8) Who will benefit? (Smith, 1999).

Rangimarie Mahuika (2008) reflects upon the indigenous research methodology and possibilities for transformation. She points out that:

"Kaupapa Māori is not about rejecting Pākehā knowledge. Instead, it is about empowering Māori, hapū and iwi to carve out new possibilities, and to determine in their own ways, their past, present and future identities and lives. Finding the correct balance and configuration within which iwi, hapū, Māori and even non-Māori knowledges and influences might be harnessed most effectively remains one of the major challenges for Māori and Māori scholars." (p. 12).

Transformation in indigenous research is greatly needed, which means taking the step from victim perspective into proactive and co-operative action. Graham Smith (2000) discusses about the importance of indigenous researchers self-critic and space for transformation. Instead of being blind for romanticizing Smith (2000) suggests:

"There is a need to sort out what is romanticized and what is real and to engage in a genuine critique of where we really are. Having said that, I think the point also needs to be made that it is all very well being engaged in deconstruction and going through an exercise of self-flagellation, but at the end of the day there must be room for change." (pp. 212-213).

\section{Critical Sámi Studies}

The role of the Sámi people as researchers started to emerge at the beginning of the 20th century. Israel Ruong (b. 1903 - d. 1986) was the first professor of Sámi descent and he acted as a researcher and as a politically active societal force (Seurujärvi-Kari, 2012). In Finland, a book "Johdatus saamentutkimukseen [Introduction to Sámi research]" discussing Sámi research was published in 1994, and it was revised in 2011 the new title being 
"Saamentutkimus tänään [Sámi research today]" (Kulonen et al., 1994; Seurujärvi-Kari et al., 2011).

Critical Sámi research covers many disciplines. Rauna Kuokkanen (see 2002; 2007; 2009) has been doing pioneering research from the critical point of view and achieved an internationally acknowledged position as a researcher of indigenous peoples. Kuokkanen (2007) calls for critical, post-colonialist research approaches to bring forward colonialist practices of the modern society. According to Kuokkanen, post-colonialist criticism can be applied for pulling down hidden consequences and colonialist heritage. This does not mean, however, that we should return to the past but becoming harmonious in order to build the future.

Sanna Valkonen (2009) did her PhD research on political Sáminess and studied the Sámi as an indigenous people during the post-colonialist era. Her research contributed an analysis of the Sámi as a people and the relationships and dynamics between the Sámi and the Sámi community. Valkonen's viewpoint provides a critical insight into the practices of modern Sáminess and the various dimensions of being a Sámi.

In Norway, Sámi research is extensive because of the numerous researchers. The powerful assimilation policy lasted in Norway for over one hundred years. It was targeted especially at Kvens and the Sámi, leaving a permanent mark on the Sámi languages and cultures, specifically among the sea Sámi (Bjørklund, 1981; 1985; 1986; Eypórsson, 2008; Gaski, 2000; Høgmo, 1986; Høgmo \& Pedersen, 2012; Minde, 2005; Paine, 1957; 2003). Line Gaski (2000) questions in her study titled "Hundre prosent lapp [One hundred percent Lapp]" the criteria of identity defined by the Sámi movement and Sámi ethno-policy, and the concept of Sámi. According to Gaski, the concept is narrow and causes the feeling of an outsider among the Sámi who live outside the Sámi residential area.

Britt Kramvig studied the identity of people living in the North-Norwegian coastal villages. She calls the population of this area blandingsfolka [mixed population] referring to the interviewees' identification in the prevailing dichotomy concerning the Sámi identity (Kramvig, 1999).

In addition, Arild Hovland has studied the problematic situation of the sea Sámi in relation to the Sámi community located in the interior of Norway. According to Hovland, the young mountain Sámi can consider their coastal peers as Norwegians. Thus, the Sámi people living by the coast have not always been defined as Sámi and accepted as Sámi like the group of hill Sámi living in the interior. Later on the situation of the sea Sámi has changed since the renaissance of Sáminess that took place in Norway. Hovland emphasizes that the arousal of Sáminess has not necessarily strengthened the identities of all sea Sámi nor have they still had achieved acceptance from the hill Sámi (Hovland, 1996; see Kramvig, 1999).

It is worth asking why the Sámi research needs critical approaches. There are many reasons for Sámi research being highly called for at the moment and the need for ways of supporting and revitalizing this indigenous culture after the powerful assimilation period is not the smallest one. Research can also enhance the inner-culture development. Critical theory can 
provide a relevant theoretical and practical foundation for research like that. Therefore, Sámi research that comes from the inside of the community is supposed to develop and support the Sámi consciousness and identity processes, and the empowerment of the Sámi community. According to Sanna Valkonen (2009, p. 31), the challenge of Sámi research is to avoid essentializing of Sáminess, renewal of the Sámi stereotypes, and avoiding the emphasis on juxtaposition. The concept of "traditional" and emphasis on the traditional culture is a significant strategy of essentialism in the indigenous rhetoric (see also Alfred, 1999). Also, Sámi research should consciously focus on sensitive themes and taboos (Gaup, 2008).

But how to study taboos that are deliberately kept silent within the community? One of the authors of this article, Erika Sarivaara (2012) located her PhD-study in the field of critical Sámi research. She combined many viewpoints to Sámi research and addressed the research phenomenon through multiple research traditions. Her study represents critical social research that reveals asymmetrical power compositions between the majority and minority inside the indigenous society. The study provided a multidimensional analysis on the position of the Sámi people as a minority.

In addition, Sarivaara's (2012) research discussed the power composition inside the Sámi community and how it influenced people's lives. This study also represent post-colonialist research because it aimed at questioning of and arousing discussion about the exercise of power within the Sámi community. The socio-linguistic perspective to the theme was discussed with the concepts and methods of the science of education. The research foci were based on the researcher's personal experiences and membership in the community. Thus, Sarivaara's research also belongs to the field of Sámi research conducted by the Sámi people themselves.

Sarivaara's study showed in practice how the researcher's role in critical Sámi research is multidimensional and active. Sarivaara herself has Sámi antecedents and speaks the Sámi language. She has worked for the Sámi community as an educator of Sámi-speaking teachers at Sámi University College. In addition, Sarivaara is a language activist in her local community in northern Finland. She has made the effort to support and revitalize the Sámi language for a long time with a special focus on the realization of human rights of the Sámi-speaking children. Still, her position in the Sámi community is not axiomatic. According to the current definition, she does not possess a Sámi status in Finland. Her research showed that there is a group of Sámi people who can be called "the Non-status Sámi”. They have revitalized the Sámi language and they have Sámi antecedents. A critical approach to the Sámi research enabled Sarivaara to introduce this marginal group within the Sámi community and question the current definition of Sáminess.

Sarivaara's study leaned on a constructivist conception of a man and knowledge which meant basically two things. It had an effect on how knowledge was constructed in the research: in collaboration with the researcher, research partners, and scientific action. On the other hand, constructivism suited well in a study in which the focus was in the revitalization of the Sámi language and Sámi identity. The main idea is that the revitalization of the Sámi language is possible to anyone and should be supported actively. Sarivaara's (2012) study also showed 
that especial cultural competence and special knowledge is required in order to understand and get in the phenomenon. Through her critical research, Sarivaara argued that the definition of Sáminess should be revised and reconsidered, and thus she presented criticism not only toward the current situation of the Sámi in relation to the mainstream society but also toward the Sámi community.

\section{Conclusion}

What is the fundamental essence of Sáminess, and how to reach it? Is it communality like in many other indigenous peoples? Smith (1999) and Battiste (2000) emphasize that the research has an important role in healing the suffering and pain and in furthering the decolonization process. According to them, research is the key to consciousness enabling healing, empowerment, and orientation to the future. The ability to critically reflect and interpret the world is not sufficient; one must also be willing and able to act to change that world (Freire, 1970).

In order to enhance necessary changes, bring forth something new, and shaken the old prejudices, we need to think about the value of the knowledge that can be produced by critical indigenous research. We also have to analyze the nature of the knowledge-for example, whether indigenous knowledge differs from scientific knowledge in general "in some essential way or merely by its origins" (Heyd, 1995, p. 64) - and make explicit our interpretations of it (see also Armstrong, Kimmerer, \& Vergun, 2007; Ellsworth, 1989). The purpose of indigenous research is to present critically and courageously the situation of the target group, and to introduce solutions that can enliven the community with the diversity of the group (see also Keskitalo, Uusiautti, \& Määttä, 2012).

FitzSimmons, Uusiautti, and Suoranta (2013) argue that "what becomes important is the breaking of human silence. We refer to the silence of the individual as they attempt to navigate life currents and also the inability of people to stand up for themselves and speak out against oppression" (p. 24). They continue that it is important "to find a way to educate individuals to actively voice their opinions and challenge what is oppressing them" (p. 24). Critical research can provide a way of giving active voices to research partners, and help them analyze the surrounding reality and opportunities and obstacles in it. Sarivaara's (2012) research results were to benefit both the Sámi and other indigenous peoples struggling with similar problems, working for saving their endangered languages, and fighting for their survival and rights.

A well-known critical intellect and educator Peter McLaren (2008) described the power of critical thinking as follows: "Teaching critically is always a leap across a dialectical divide that is necessary for any act of knowing to occur. Knowing is a type of dance, a movement, but a self-conscious one. Criticality is not a line stretching into eternity, but rather it is a circle. In other words, knowing can be the object of our knowing, it can be self-reflective, and it is something in which we can make an intervention. In which we must make an intervention" ( $\mathrm{p}$. 476). McLaren's words can be translated by referring to Balto (2008) who brings out that thoughts have an enormous power. Consciousness of one's feelings and thoughts, actions and prejudices, can help finding cures and promoting practices in indigenous communities. Balto 
(2008) also specifies that knowing the Sámi's rights is a significant prerequisite of developmental work. The revitalization of indigenous languages is a central tool of decolonization process.

The situation of the Sámi in Finland is a struggle for survival in an oppressed position. Divide and conquer is a mechanism of power that rests on idea of people being unequal (see also Posner, Spier, \& Vermeule, 20010; Greenbaum, 1974). One solution could be John Galtung's both-and principle in which adversaries familiarize themselves with each other's points of view. Then, they might be able to come up with new and creative ideas, win-win solutions (Galtung, 2003). There are already examples of such solutions in Finland (see e.g., Lindgren \& Lindgren, 2006).

Indigenous peoples must confront existing colonial practices and structures and actively engage in everyday practices of revitalization (Corntassel, 2012). Information produced by critical Sámi research is to heal the wounds of the Sámi living the post-colonialist times. It means that most Sámi people have been assimilated linguistically and culturally in the mainstreaming Finnish society. However, the research shows that the revitalization of the Sámi language has strong foundation and fertile ground. Nevertheless, the process has obstacles related to the complex Sámi identity (Sarivaara, 2012; Sarivaara, Määttä, \& Uusiautti, 2013; Sarivaara \& Uusiautti, 2013; Sarivaara, Uusiautti, Määttä, 2013ab). People who live in the borders of the Sámi community have to be noticed and the resources and strength they have should be employed: they make a significant add to the revitalization of the Sámi language and culture. In other words, the Sámi community should open the door for these people left outside and thus save the marginal of the culture in order to strengthen the Sámi identity and making it visible. It is time to rethink our ideologies and search for new ways of revising our preconceived ideas of how to see the world (Roine, 2010). A critical viewpoint to tolerance and faith might be the key. According to Freire (1998), to have faith "demands a stand for freedom, which implies respect for the freedom of others, in an ethical sense, in the sense of humility, coherence, and tolerance" (Freire, 1998, p. 105). But this also necessitates action and engagement. Indeed, as Greenbaum (1974) felicitously pointed out in his essay on the rise of pluralist society, it is not enough just trying to be hopeful or encourage hopefulness in others!

Critical Sámi research has its place in this endeavor because without research-based knowledge and critical analysis of the reality no change can occur (cf. Kincheloe \& McLaren, 2005). When the purpose is to gain self-determination, everyone supporting the process must be considered valuable.

\section{References}

Alfred, T. (1999). Peace, power, righteousness: An indigenous manifesto (Vol. 171). Don Mills: Oxford University Press.

Anttila, P. (2006). Tutkiva toiminta ja ilmaisu, teos, tekeminen [Researching action and expression, work, doing]. Hamina: Akatiimi

Armstrong, M., Kimmerer, R. W., \& Vergun, J. (2007). Education and research opportunities 
for traditional ecological knowledge. Frontiers in Ecology and the Environment, 5(4), W12-W14. http://dx.doi.org/10.1890/1540-9295(2007)5[w12:EAROFT]2.0.CO;2

Balto, A. (1997). Sámi mánáidbajásgeassin nuppástuvvá [Sámi upbringing in change]. Oslo: ad Notam Gyldendal.

Balto, A. (2008). Sámi oahpaheaddjit sirdet árbevirolaš kultuvrra boahttevaš buolvvaide. Dekoloniserema akšuvdnadutkamuš Ruota beale Sámis [Sámi teachers pass the traditional culture to the next generations]. (Dieđut 4/2008). Guovdageaidnu: Sámi allaskuvla.

Bjørklund, I. (1981). Hva med sjøsamene? [What about the Coastal Sámi?] Ottar, 129, 31-34.

Bjørklund, I. (1985). Fjordfolket $i$ Kvanangen. Fra samisk samfunn til norsk utkant 1550-1980 [Fjord people of Kvænangen. From Sami community to Norwegian outlying 1550-1980]. Tromsø: Universitetsforlaget.

Bjørklund, I. (1986). Hvordan nordmenn ble flere og samer ble færre [How Norwegians become more and Sami become fewer]. In R. Erke \& A. Høgmo (Eds.), Identitet og livsutfoldelse. En artikkelsamling om flerfolkelige samfunn med vekt på samenes situasjon [Identity and self-expression. A collection of articles about more popular communities with emphasis on Sami’s situation] (pp. 67-73). Tromsø: Universitetsforlaget.

Botes, L., \& van Rensburg, D. (2000). Community participation in development: nine plagues and twelve commandments. Community Development Journal, 35(1), 41-58. http://dx.doi.org/10.1093/cdj/35.1.41

Breie Henriksen, M. (2009). Sáhttá go dieđateorehtalaččat ákkastallat dieđagiela válljema? [Is it possible to epistemologically justify the selection of scientific language?] Program for samisk forskning II - Norges forskningsråd Kautokeino 26.-27 Nov 2010. Oslo: $\begin{array}{lllll}\text { Forskningsrådet. } & \text { Retrieved } & \text { July } & 7, & 2013,\end{array}$ http://www.forskningsradet.no/no/Nyheter/Program_for_samisk_forskning_II_Vellykket_kon feranse_i_Kautokeino/1253953454600

Carr, W., \& Kemmis, S. (1986). Becoming critical: Education, knowledge and action research. London: Falmer.

Chambers, S. (2006). The politics of critical theory. In F. Rush (Ed.), The Cambridge companion to critical theory (pp. 219-247). Cambridge: Cambridge University Press.

Collins, J. (2009). Social reproduction in classrooms and schools. Annual Review of Anthropology, 38, 33-48. http://dx.doi.org/10.1146/annurev.anthro.37.081407.085242

Connelly, B. (1996). Interpretations of Jurgen Habermas in adult education writings. Studies in the Education of Adults, 28(2), 241-253.

Corntassel, J. (2012). 'Re-envisioning resurgence: Indigenous pathways to decolonization and -sustainable self-determination'. Decolonization: Indigeneity, Education \& Society, 1(1), 86-101.

Díaz de Rada, A. (2007). School bureaucracy, ethnography and culture: Conceptual obstacles 
to doing ethnography in schools. Social Anthropology/Anthropologie Sociale, 15(2), 205-222. http://dx.doi.org/10.1111/j.0964-0282.2007.00017.x

Ecclestone, K. (1996). The reflective practitioner. Studies in the Education of Adults, 28(2), 146-162.

Ellsworth, E. (1989). Why doesn't this feel empowering? Working through the repressive myths of critical pedagogy. Harvard Educational Review, 59(3), 297-324.

Eikjok, J. (2000). Indigenous women in the north: The struggle for rights and feminism. Indigenous Affairs, 3, 38-41.

Eikjok, J. (2007). Gender, essentialism and feminism in Samiland. In J. Green (Ed.), Making space for Indigenous feminism (pp. 108-123). Halifax: Fernwood Press.

Eriksen, K. (2007). Iešmearrideapmi hástá suverenitehta. Ságastallan álgoálbmogiid iešmearrideamis Ovttastuvvan Našuvnnaid álgoálbmotjulggaštus -bargojoavkkus [Self-determination challenges sovereignty. Discussion about Indigenous Peoples' self-determination within the United Nations Declaration on the Indigenous peoples working group United Nations]. (Master's thesis, University of Lapland, Finland).

Eypórsson, E. (2008). Sjøsamene og kampen om fjordressursene [The Coastal Sámi and struggle over land resources]. Kárášjohka-Karasjok: ČálliidLágádus.

Fanon, F. (1959). Studies in a dying colonialism. Harmondsworth: Penguin.

Fanon, F. (1961). The wretched of the earth. Harmondsworth: Penguin.

Fanon F. (1952/1967). Black skin, white masks. New York, NY: Grove Press.

FitzSimmons, R., \& Uusiautti, S. (2013). Critical revolutionary pedagogy spiced by pedagogical love. Journal for Critical Education Policy Studies, 11(3), 230-243.

FitzSimmons, R., Uusiautti, S., \& Suoranta, J. (2013). An action-oriented critical pedagogical theory. Journal of Studies in Education, 3(2), 21-35. http://dx.doi.org/10.5296/jse.v3i2.3203

Freire, P. (1970). Cultural action and conscientization. Harvard Educational Review, 40(3), 452-477.

Freire, P. (1972). Pedagogy of the oppressed. Harmondsworth: Penguin Education.

Freire, P. (1998). Pedagogy of the heart. New York, NY: Continuum.

Galtung, J. (2003). Både og. En innføring $i$ konliktarbeid [Both-and. An introduction to conflict work]. Oslo: Kagge.

Gaski, L. (2000). Hundre prosent lapp? Lokale diskurser on etnisitet i markbygdene i Evenes og skånland [One hundred percent Lapp? Local discourses on ethnicity in the interior villages in Evenes and Skånland]. (Dieđut 5/2000.) Guovdageaidnu: Sámi Instituhtta.

Gaski, L. (2008). Norwegian Sami identity as a discursive formation: essentialism and ambivalence. In H. Minde, S. Jentoft, H. Gaski, \& G. Midré (Eds.), Indigenous peoples: 
self-determination, knowledge, indigeneity (pp. 219-236). Delft: Eburon.

Gaup, K. E. (2008). Ehtalaš jurddašeamit, čuolmmat ja hástalusat dutkanfáttáid válljemis ja fealtabargguid oktavuođas [Ethical thoughts, problems, and challenges in the selection of a research theme and field research in the Sámi residential area]. In Ethics in Sámi and Indigenous Research. Report from a seminar i Kárášjohka, Norway, November 23-24, 2006 (pp. 87-93). Guovdageaidnu: Sámi Instituhtta.

Greenbaum, W. (1974). America in search of a new ideal: an essay on the rise of pluralism. Harvard Educational Review, 44(3), 411-440.

Habermas, J. (1976). Tieto ja intressi [Knowledge and interest]. In R. Tuomela \& I. Patoluoto (Eds.), Yhteiskuntatieteiden filosofiset perusteet I [The philosophical foundation of social sciences I] (pp. 118-141). Helsinki: Gaudeamus.

Habermas, J. (1987). Knowledge and human interest. Cambridge: Polity Press.

Hart, M. A. (2010). Indigenous worldviews, knowledge, and research: The development of an indigenous research paradigm. Journal of Indigenous Voices in Social Work, 1(1), 1-16.

Heikkinen, H. L. T. (2001). Toimintatutkimus - Toiminnan ja ajattelun taitoa [Action research - mastery over action and reflection]. In J. Aaltola \& R. Valli (Eds.), Ikkunoita tutkimusmetodeihin I. Metodin valinta ja aineiston keruu: virikkeitä aloittelevalle tutkijalle [Introduction to research methods I. The selection of a method and data collection: stimuli for beginning researchers] (pp. 170-185). Jyväskylä: PS-kustannus.

Held, D. (1987). Introduction to critical theory from Horkheimer to Habermas. London: Hutchinson.

Henrickson, L., \& McKelvey, B. (2002). Foundations of "new" social science: Institutional legitimacy from philosophy, complexity science, postmodernism, and agent-based modeling. Proceedings of the National Academy of Sciences of the United States of America, 99(Supp. 3), 7288-7295. http://dx.doi.org/10.1073/pnas.092079799

Henry, J., Dunbar, T., Arnott, A., Scrimgeour, M., \& Murakami-Gold, L. (2004). Indigenous Research Reform Agenda. A review of the literature. Links Monograph Series, 5/2004. Retrieved from https://lowitja.org.au/sites/default/files/docs/IRRA5LinksMonographs.pdf

Heyd, T. (1995). Indigenous knowledge, emancipation and alienation. Knowledge and Policy, 8(1), 63-73. http://dx.doi.org/10.1007/BF02698557

Hirvonen, V. (1999). Sámeeatnama jienat. Sápmelaš nissona bálggis girječállin [Voices from Sápmi: Sámi women's path to authorship]. Guovdageaidnu: DAT.

Hirvonen, V. (2003). Mo sámáidahttit skuvlla? Reforpma 97 evalueren [How to assimilate the school into Sámi? Evaluation of the Reform 97]. Kárášjohka: Č́lliidLágádus.

Hovland, A. (1996). Moderne urfolk. Samisk ungdom i bevelgelse [Sámi youngsters in move]. Cappelen: Akademisk Forlag. 
Huttunen, R. (2003). Kommunikatiivinen opettaminen [Communicative teaching]. Jyväskylä: SoPhi.

Høgmo, A. (1986). Det tredje alternative [The third alternative]. Tidsskrift for samfunnsforskning, 1986:5.

Høgmo, A., \& Pedersen, P. (2012). SÁPMI slår tilbake. Samiske revitaliserings- og moderniseringsprosesser $i$ siste generasjon [Sápmi hits bak. The revitalization and modernization of the Sámi in the latest generation]. Karasjok: CálliidLágádus.

Keskitalo, P. (2010). Saamelaiskoulun kulttuurisensitiivisyyttä etsimässä kasvatusantropologian keinoin [Cultural sensitivity in the Sámi school through educational anthropology]. (Dieđut 1/2010.) Guovdageaidnu: Sámi allaskuvla.

Keskitalo, P., Määttä, K., \& Uusiautti, S. (2013). Sámi education. Frankfurt am Main: Peter Lang.

Keskitalo, P., Uusiautti, S., \& Määttä, K. (2012). How to make the small indigenous cultures bloom? Special traits of Sámi education in Finland. Current Issues in Comparative Education: Education in Small States, 15(1), 52-62.

Kiilakoski, T., \& Oravakangas, A. (2010). Koulutus tuotantokoneistona? Tulostavoitteinen koulutuspolitiikka kriittisen teorian valossa [Education as production? Goal-oriented education policy in the light of critical theory]. Kasvatus \& Aika, 4(1), 7-25.

Kincheloe, J. L., \& McLaren, P. (2005). Rethinking critical theory \& qualitative research. In N. K. Denzin \& Y. S. Lincoln (Eds.), The SAGE handbook of qualitative research (pp. 303-342). Thousand Oaks, CA: Sage.

Kramvig, B. (1999). I kategoriens vold [In the violence of category]. In H. Eidheim (Ed.), Samer og nordmenn [The Sámi and the Norwegians] (pp. 117-140). Oslo: Cappelen Akademiske Forlag.

Kulonen, U.-M., Pentikäinen, J., \& Seurujärvi- Kari, I. (1994). Johdatus saamentutkimukseen [Introduction to Sámi research]. Helsinki: The Finnish Literature Society.

Kulonen, U.-M., Seurujärvi-Kari, I., \& Pulkkinen, R. (Eds.) (2005). The Saami. A cultural encyclopaedia. Helsinki: The Finnish Literature Society.

Kuokkanen, R. (1999). Etnostressistä sillanrakennukseen. Saamelaisen nykykirjallisuuden minäkuvat [From ethno-stress to bridge building. Self-images of the modern Sámi literature]. In M. Tuominen, S. Tuulentie, V.-P. Lehtola, \& M. Autti (Eds.), Pohjoiset identiteetit ja mentaliteetit, osa I: Outamaalta tunturiin [Northern identities and mentalities, part I] (pp. 95-112). Rovaniemi: Lapland University Press.

Kuokkanen, R. (2000). Towards an 'Indigenous Paradigm' from a Sami Perspective. The Canadian Journal of Native Studies, 20(2), 411-436.

Kuokkanen, R. (2002). Alkuperäiskansojen diskurssi ja dekolonisaatio [The indigenous discourse and decolonization]. In S. Lakomäki \& M. Savolainen (Eds.), Kojootteja, 
Sulkapäähineitä, uraanikaivoksia. Pohjois-Amerikan intiaanien kirjallisuuksia ja kulttuureja [Coyotes, feathered headgear, urane mines. Literatures and cultures of the North-American Indians] (pp. 240-264). Oulu: University of Oulu.

Kuokkanen, R. (2006). Indigenous Peoples on two continents: self-determination processes in Sámi and First Nations societies. European Review of Native American Studies, 20(2), 25-30.

Kuokkanen, R. (2007). Myths and realities of Sami women: A post-colonial feminist analysis for the decolonization and transformation of Sami society. In J. Green (Ed.), Making space for Indigenous feminism (pp. 72-92). Halifax: Fernwood Press.

Kuokkanen, R. (2009). Boaris dego eana. Eamiálbmogiid diehtu, filosofiijat ja dutkan [As old as the land. Indigneous knowledge, philosophy, and research]. Kárašjohka: Č́lliidLágádus.

Kuortti, J. (2007). Jälkikoloniaalisia käännöksiä [Post-colonialist translations]. In J. Kuortti, M. Lehtonen, \& O. Löytty (Eds.), Kolonialismin jäljet. Keskustat, periferiat ja Suomi [The marks of colonialism. Centers, periferia, and Finland]. Helsinki: Gaudeamus.

Kymlicka, W. (1998). Human rights and ethnocultural justice. Review of Constitutional Studies, 4(2), 213-237.

Lehtola, V.-P. (1996). Nimettömän kansan historiasta. Saamelaisten historiantutkimuksen näkymiä [About the history of people without a name. Perspectives to Sámi history research]. Historia Fenno-Ugrica, 1(1-2), 11-22.

Lehtola, V.-P. (1997). Rajamaan identiteetti. Lappilaisuuden rakentuminen 1920- ja 1930-luvun kirjallisuudessa [Identity of borderland. The construction of Lappishness in the literature of the 1920s and 1930s]. Helsinki: The Finnish Literature Society.

Lehtola, V.-P. (2005). Saamelaiset itse tutkimuksensa tekijöiksi [The Sámi should become Sámi researchers]. Kaltio, 5/2005.

Lindgren, K., \& Lindgren, A.-R. (2006). Suomen suuriruhtinaanmaan säätyläisten kielenvaihto [Language shift among the gentry of the Finnish grand duchy]. In G. Bladh \& C. Kuvaja (Eds.), Kahden puolen Pohjanlahtea 1. Ihmisiä, yhteisöjä ja aatteita Ruotsissa ja Suomessa 1500-luvulta 1900-luvulle [On both coasts of the Gulf of Bothnia i. People, communities, and ideologies in Finland and Sweden from the 16th century to the 20th century] (pp. 326-396). Helsinki: The Finnish Literature Society.

Länsman, A.-S. (2008). Kenelle saamentutkija tutkii? [To whom is the researcher doing Sámi research?] In K. Lempiäinen, O. Löytty, \& M. Kinnunen (Eds.), Tutkijan kirja [A researcher's book] (pp. 87-98). Tampere: Vastapaino.

Mahuika, R. (2008). Kaupapa Māori theory is critical and anti-colonial. MAI Review, 3(4). Retrieved from: http://www.review.mai.ac.nz/index.php/MR/article/viewFile/153/180

Marker, M. (2000). Lummi identity and white racism: When location is a real place International Journal of Qualitative Studies in Education, 13(4), 401-414. 
http://dx.doi.org/10.1080/095183900413359

McLaren, P. (2008). This fist called my heart: public pedagogy in the belly of the beast. Antipode, 40(3), 472-481. http://dx.doi.org/10.1111/j.1467-8330.2008.00616.x

Minde, H. (2005). Fornorskinga av samene - hvorfor, hvordan og hvilke følger [Assimilation of the Sami - why, how and what consequences]. Gáldu čála, 3/2005.

Niemi, E. (1997). Kulturmøte, etnisitet og statlig intervensjon på Nordkalotten [Cultural encounter, ethnicity, and national intervention at the Cap of the North]. In R. Boström Andersson (Ed.), Den nordiska mosaiken: språk- och kulturmöten i gammal tid och $i$ våra dagar [The Nordic mosaic: linguistic and cultural encounter before and today]. Uppsala: University of Uppsala.

Paine, R. (1957). Coast Lapp society I. Tromsø: Tromsø museum.

Paine, R. (2003). Identititetsfloke same - same. Om komplekse identitetsprosesser i samiske samfunn [On complex identity processes in the Sámi community]. In B. Bjerkli \& P. Selle (Eds.), Samer, makt og demokrati [The Sámi, power, and democracy] (pp. 291-317). Oslo: Gyldendal akademisk.

Pietilä, P. (2009). A space of our own. Non-formal education for elder women in Andalusia. European Journal of Women's Studies, 16(1), 53-66. http://dx.doi.org/10.1177/1350506808098534

Porsanger, J. (2007). Bassejoga čáhci. Gáldut nuortasámiid eamioskkoldaga birra álgoálbmotmetodologiijaid olis [The waters of the holy river. The sources of the East Sami religion in light of indigenous methdology]. Kárášjohka: Davvi girji.

Posner, E. A., Spier, K. E., \& Vermeule, A. (2010). Divide and conquer. Journal of Legal Analysis, 2(2), 417-471. http://dx.doi.org/10.1093/jla/2.2.417

Pulkkinen, R. (2000). Myyttiset saamelaiset [The mythical Sámi]. In I. Seurujärvi-Kari (Ed.), Beaivvi mánát. Saamelaisten juuret ja nykyaika [The Sámi antecedents and present time] (pp. 41-64). Helsinki: The Finnish Literature Society.

Rautio Helander, K. (2008). Namat dan nammii. Sámi báikenamaid dáruiduhttin Várjjaga guovllus Norgga uniovdnaáiggi loahpas [In the name of names. The Norwegianization of the Sámi placenames in the Várjjat area at the end of the unification period of Norway]. (Dieđut 1/2008.) Guovdageaidnu: Sámi allaskuvla.

Roine, A. (2010). Best available world: a manifesto for a new future. Helsinki Times, 25-26.

Rosaldo, M. Z. (1980). The use and abuse of anthropology: reflections on feminism and cross-cultural understanding. Signs, 5(3), 389-417. http://dx.doi.org/10.1086/493727

Sarivaara, E. K. (2012). Statuksettomat saamelaiset. Paikantumisia saamelaisuuden rajoilla [The Non-Status Sámi. Identities at the borderline of Sáminess]. (Dieđut 2/2012, PhD. diss. University of Lapland, Rovaniemi, Finland). Guovdageaidnu: Sámi allaskuvla. 
Sarivaara, E., Määttä, K., \& Uusiautti, S. (2013). Sensitivity in indigenous identity research. European Social Sciences Research Journal, 1(2), 145-157.

Sarivaara, E., \& Uusiautti, S. (2013). Taking care of the ancestral language: the language revitalization of Non-Status Sámi in Finnish Sápmi. International Journal of Critical Indigenous Studies, 6(1), 1-16.

Sarivaara, E., Uusiautti, S., \& Määttä, K. (2013). How to revitalize an indigenous language? Adults' experiences of the revitalization of the Sámi language. Cross-Cultural Communication, 9(1), 13-21. doi: 10.3968/j.ccc.1923670020130901.2121

Sarivaara, E., Uusiautti, S., \& Määttä, K. (2013). The position and identification of the Non-Status Sámi in the marginal of indigeneity. Global Journal of Human and Social Sciences, 13(1), 23-33.

Schanche, A. (2002). Saami skulls, anthropological race research and the repatriation question in Norway. In C. Forde, J. Hubert, \& P. Turnbull (Eds.), The Dead and their possessions: repatriation in principle, policy and practice (pp. 47-58). London: Routledge.

Schefferus, J. (1963). Lapponia eli Lapin maan ja kansan uusi ja todenmukainen kuvaus [Lapponia aka the Lapland, and the new and truthful description of the people]. Hämeenlinna: Karisto.

Seurujärvi-Kari, I. (2012). Ale jaskkot eatnigiella. Alkuperäiskansaliikkeen ja saamen kielen merkitys saamelaisten identiteetille [Mother tongue, do not get silenced. The meaning of the indigenous movement and the Sámi language to the Sámi identity]. Helsinki: University of Helsinkil

Seurujärvi-Kari, I., Halinen, P., \& Pulkkinen, R. (Eds.) (2011). Saamentutkimus tänään [Sámi research today]. Helsinki: The Finnish Literature Society.

Smith, G. H. (2000). Protecting and respecting indigenous knowledge. In M. Battiste (Ed.), Reclaiming Indigenous voice and vision (pp. 209-224). Canada: UBC Press.

Smith, L. T. (1999). Decolonizing methodologies: research and indigenous peoples. London: Zed Books.

Stordahl, V. (1996). Same $i$ den moderne verden. Endring og kontinuitet $i$ et samisk lokalsamfunn [The Sámi in the modern world. Change and continuation in a Sámi local community]. Karasjok: Davvi Girji.

Stromquist, N. P. (2013). Education policies for gender equity: probing into state responses. Education Policy Analysis Archives, 21(65) Retrieved 27 August 2013, from http://epaa.asu.edu/ojs/article/view/1338

Suoranta, J. (2005). Radikaali kasvatus [Radical education]. Tampere: Gaudeamus.

Vahtola, J. (1983). Maailmanmatkaajia Lapissa [Traveling in Lapland]. In Lappi 1. Suuri, kaunis pohjoinen maa [Lapland 1. A large, beautiful northern land] (pp. 135-161). Hämeenlinna: Karisto. 
Valkonen, S. (2009). Poliittinen saamelaisuus [Political Sáminess]. Tampere: Vastapaino.

Williams, S. E., \& Finger Wright, D. (1992). Empowerment. The strengths of black families revisited. Journal of Multicultural Social Work, 2(4), 23-36. http://dx.doi.org/10.1300/J285v02n04_03

\section{Copyright Disclaimer}

Copyright reserved by the author(s).

This article is an open-access article distributed under the terms and conditions of the Creative Commons Attribution license (http://creativecommons.org/licenses/by/3.0/). 